This is an electronic reprint of the original article. This reprint may differ from the original in pagination and typographic detail.

Author(s): Kuutti, Heikki; Lauk, Epp

Title: $\quad$ Ethical demands and responsibilities in online publishing. The Finnish experience

Year: $\quad 2014$

Version:

Please cite the original version:

Kuutti, H., \& Lauk, E. (2014). Ethical demands and responsibilities in online publishing. The Finnish experience. In E. Psychogiopoulou (Ed.), Media Policies Revisited. The Challenge for Media Freedom and Independence (pp. 234-248). Palgrave Macmillan. https://doi.org/10.1057/9781137337849_17

All material supplied via JYX is protected by copyright and other intellectual property rights, and duplication or sale of all or part of any of the repository collections is not permitted, except that material may be duplicated by you for your research use or educational purposes in electronic or print form. You must obtain permission for any other use. Electronic or print copies may not be offered, whether for sale or otherwise to anyone who is not an authorised user. 


\section{Ethical demands and responsibilities in online publishing: The Finnish experience}

Epp Lauk and Heikki Kuutti

In: Media freedom and independence: Policy challenges and regulatory trends in Europe. Evangelia Psychogiopoulou (ed). Palgrave Macmillan,234-248. 2013.

\section{Introduction}

Rapid advancement of online communication and publishing poses new challenges to media policy-makers and regulators for both statutory regulation and self-regulation. For journalists, 'the Internet shapes and redefines a number of moral and ethical issues /---/ when operating online or making use of online resources' (Deuze and Yeshua, 2001: 276).

The Internet has opened unlimited space for publishing of anything by anybody who has online access. All traditional mass media have web versions, which do not only contain editorial material, but often provide the public with a space for debate and comments. This way, the Internet has added a new dimension to the freedom of the press and freedom of expression. However, alongside broadened possibilities for the news media to fulfil their public service duties and interact with audiences, a number of ethical matters arise. The Internet retains almost anything once published, mistakes are difficult to correct, Internet anonymity encourages distributing hate speech, and so on. While news media take responsibility for the editorial content of their web publications, the pertinent question is what responsibility they take for the rest of the content they publish.

The regulation of the Internet is a highly problematic and sensitive issue as it tests the limits of the freedom of expression. Therefore, the importance of addressing ethical questions within the framework of media's self-regulation increases remarkably. A major value for the news media is credibility. Various means for supporting the media's credibility can be found within self-regulatory frameworks, extended to the media online, especially in those media systems where self-regulation has a long tradition, such as in Finland. The Finnish media system represents the 'democratic corporatist model' (Hallin and Mancini, 2004) with a well-developed media autonomy, high level of journalistic professionalism, high degree of authority of self-regulatory mechanisms and strong professional organisations of journalists.

This chapter focuses on how the ethical issues of online publishing are regulated in Finland. The next part discusses the impact of the Internet on journalism, identifying the publishing challenges that the online environment has created for media companies and journalists in Finland. The following part focuses on the Finnish Internet legislation from the perspective of its effect on journalism ethics. A particularly important issue here is the moderation of online discussion forums and the different types of responsibility acknowledged for the author and the publisher of unlawful content. Ethical issues in online journalism are then discussed, through an examination of the recommendations and guidelines that the Finnish Council for Mass Media (CMM), the self-regulatory body for all Finnish news media, has formulated on the basis of adjudicated cases. Practices and guidelines for moderating online discussion forums and comment boxes as parts of the news media's web publications are also analysed. Additionally, the guidelines of media organisations for journalists' use of social media are discussed.

The analysis in this chapter is based on relevant journalism research, ethical guidelines, policy statements and cases adjudicated by the CMM. Research material also includes media companies' strategy papers and guidelines regarding the moderation of 
their discussion forums and employees' performance in social media, interviews with chief editors and survey data.

\section{Internet usage and new challenges for media policy, online journalism and online publishing}

Since 2000, the use of the Internet among the Finnish population has been supported by the government's Information Society Programmes (2003-2007 and 2007-2015). In 2009, the government announced Finland to be the first country in the world that would provide every household with access to fast broadband Internet by law. According to Akamai Technologies Inc.'s latest report (first quarter 2012), Internet connections' speed in Finland has grown 39 per cent within the past year, and was 6.9 Mbps in early 2012, which places Finland $10^{\text {th }}$ globally (Akamai, 2012). With current Internet penetration at 89.4 per cent, Finland occupies the $9^{\text {th }}$ position amongst the European countries (Internet World Stats, 2012).

Among the most popular activities of the Finnish population online, other than social media, ${ }^{1}$ are reading newspapers and searching for information. However, the majority of Finns still read newspapers offline (about 94 per cent do so at least once a week), although the number of those who regularly read online versions is growing. Today, 62.9 per cent of the Finnish population over 12 years old reads newspapers on computers. The proportion of those who read newspapers on mobile phones has almost doubled within a year (from 8.1 per cent in spring 2011 to 15.1 per cent in spring 2012), and 4.5 per cent use tablets for reading newspapers (Kansallinen Mediatutkimus, 2012). The most popular media websites (excluding news portals) are those of two evening newspapers (Ilta-Sanomat and Iltalehti) and of broadcasters (the public service television YLE and commercial channel MTV3). Several media outlets have profiles on Facebook, and practically all Finnish journalists use social media to some degree in their work (Laine, 2010).

Expanding online publishing generates problems that need the attention of media policy-makers and experts as well as media practitioners. As a response to the Additional Protocol to the Convention on Cybercrime of the Council of Europe, concerning the criminalisation of acts of a racist and xenophobic nature on the Internet, ${ }^{2}$ many countries have introduced laws on these specific aspects online. The demarcation line between restricting the lawful right to free expression and preventing distribution of harmful and unlawful content is, however, rather ambiguous and open to interpretation. In Finnish legislation, the restrictions are mainly aimed at the format and the ways of expression rather than the content. The regulations do not limit participation in public debate on politically or otherwise sensitive issues, but forbid agitation directed against public security, personal safety or human integrity.

The Internet has also generated a new kind of journalism - online journalism with its own media logic and specific characteristics (Deuze and Yeshua, 2001; Deuze, 2003; 2008; Pavlik, 2000). Deuze (2003: 206) points out three such basic characteristics

\footnotetext{
${ }^{1}$ Facebook penetration was 40.2 per cent in Finland in March 2012 (Internet World Stats 2012).

${ }^{2}$ See http://conventions.coe.int/Treaty/en/Treaties/Html/189.htm, date accessed 18 December 2012.
} 
that differentiate online journalism: multimediality, interactivity and hypertextuality. As explained:

'The online journalist has to make decisions as to which media format or formats best convey a certain story (multimediality), consider options for the public to respond, interact or even customize certain stories (interactivity), and think about ways to connect the story to other stories, archives, resources and so forth through hyperlinks (hypertextuality).'

On the Web, static stories of the traditional media become a process with audiovisual and interactive elements; the scheduled deadline-time of publishing becomes a nonstop online time.

Deuze (2003: 208-211) identifies four types of news sites that can be considered to belong to the professional domain of journalism: first, mainstream news sites offering original or aggregated editorial content (most online newspapers and news portals); second, index and category sites that provide annotated links to content elsewhere and maintain some kind of bulletin board system; third, meta- and comment sites about news media and media in general ('journalism about journalism'), sometimes intended as 'media watchdogs', or media critiques; fourth, share and discussion sites that facilitate more or less edited platforms for the exchange of ideas and stories, often focused on a specific theme (e.g. European Journalism Observatory).

A major part of online publishing is not journalistic production, but entirely usergenerated non-edited content (such as discussion forums or comments to stories, and blogs). Also social media are not journalism, although they often substitute for journalistic products. User-generated content and social media are the 'gray' areas for media policy, where it is not always clear which elements should be regulated by laws, and which by the conventions of media's self-regulation.

\section{Statutory regulation of online publishing}

The laws that regulate the traditional media usually also apply to the websites of media outlets, and put responsibility for editorial content on the news medium concerned. However, this is not wholly sufficient, as the online versions also host user-generated (and often anonymous) content in various formats (cf. Jönsson and Örnebring, 2011; Hlavach and Freivogel, 2011). The question of to what extent the site owner is legally and morally responsible for this content is especially sensitive from the viewpoint of the freedom of expression. Internet users expect unlimited freedom of expression at any time, and the forums and discussion boards do not usually moderate themselves. At the same time, the Internet has become a much-used channel for spreading hate speech, and an organising tool for hate groups, which now can reach much larger audiences than ever before (cf. Leets, 2001; Perry and Olsson, 2009).

\subsection{Legislative measures for Internet regulation}

The Act on the Exercise of the Freedom of Expression in Mass Media (460/2003 $\left.{ }^{3}\right)$ - the Freedom of Expression Act (FEA) - deals with the press, broadcasting and online media within the same framework with respect to their responsibility and the freedom of

\footnotetext{
${ }^{3}$ See http://www.finlex.fi/fi/laki/kaannokset/2003/en20030460.pdf, date accessed 9 September 2012.
} 
expression. For managing and supervising editorial work and deciding on the contents, the law requires that each periodical publication, including online publications, must have a responsible editor (FEA, Chapter 2, section 4).

The FEA (Chapter 1, section 2) distinguishes between an online (network) publication and a network message. A 'network message' means information, an opinion or some other message provided to the public by means of radio waves, an electronic communications network or some other comparable technical arrangement. A 'network publication' means a set of network messages, arranged into a coherent whole comparable to a periodical from material produced or processed by the publisher, and intended to be issued regularly. In addition, the FEA requires programmes and publications to be recorded, and recordings to be retained for 21 days (Chapter 2, section 6). Everyone who feels victimised or harmed by a programme or network publication, or wishes to reply or make a correction, has the right of access to these recordings at no cost (Chapter 4, section 15).

The FEA limits the responsibility of the 'publisher, broadcaster or keeper of a transmitter, server or other comparable device' (Chapter 5, section 18) to technical and distributional matters (e.g. the obligation to delete unlawful material after a court decision). In 2011, new amendments to the Penal Code came into force, which specify the responsibility of the web masters for the content of their sites. Before the enforcement of these amendments, unlawful material could only be removed after a court decision. According to the amendments, intentionality of keeping unlawful material publicly available becomes a decisive factor. If the webmasters intentionally do not remove harmful material after due notice, they can be sued according to the articles of the Penal Code concerning hostile ethnic agitation or dissemination of sexually obscene material (Finnish Ministry of Justice, 2011).

To protect data and personal privacy in electronic communication, according to EU directives, Finland has passed the Act on Protection of Privacy in Electronic Communication $(516 / 2004 \text { with the latest amendments by } 374 / 212)^{4}$. The Act covers aspects that are not covered by the general Personal Data Act and Penal Code, such as information security, direct marketing and service providers' processing of identification data.

\subsection{Legal issues in practice}

So far, in Finnish judicial practice, a few rare cases deal with the responsibility of the authors of 'network messages' for hate speech and aggravated ethnic agitation. There are yet no cases dealing with a similar responsibility of site owners or web masters.

The court practice demonstrates how complicated it is to draw a line between lawful and unlawful content. Therefore, the courts consider contextual factors, such as the intentionality of publishing and the extent of harm caused. Public figures, especially politicians are expected to withstand quite harsh public criticism and rude expressions while their activities are under evaluation. However, only offensive, vilifying or threatening messages are considered to be breaches of the law. The Court of Appeal, in a July 2011 decision, concerning a website that called for killing an MP, the then Minister

\footnotetext{
${ }^{4}$ See http://www.finlex.fi/fi/laki/smur/2004/20040516, date accessed 19 December 2012.
} 
of Migration and European Affairs, concluded that threatening anybody with crime or being personally denigrating, never belongs within the limits of the freedom of expression. The court emphasised that the website's author had not criticised the work of the minister but severely offended her as a human being. Furthermore, the author had made efforts to gain as much publicity as possible for the website, increasing the probability of real danger to the life of the minister. The sentence, handed down by the court, was three months conditional imprisonment for threatening the minister's life, defamation, and ethnic agitation (MTV3, 2011). In another case, where a person posted a statement to an open discussion forum 'I alone could shoot the Minister of Finance and Prime Minister and blow up Parliament', the court decided that there was no evidence of real intent of violence or clear danger to anybody's lives. In this case, the message was considered as an expression of frustration and angst over the economic and political situation (YLE, 2011). In May 2012, the North-Karelian district court adjudicated the first Facebook case in Finland about disseminating racist hatred online. A group of eight individuals was charged with the website publication of messages and videos, which clearly indicated that violence against immigrants is desirable, and was found to offend and traduce immigrants of other ethnic origin (MTV3, 2012).

\section{Ethical issues of online journalism}

The ethics of journalism are understood as the dominant attitudes and norms shaping journalistic practice (Ward, 2005). In their institutionalised format, these principles and norms are articulated as codes of ethics or codes of professional conduct and are to be voluntarily adhered by journalists. In the 1990s, surveys signalled a strong legitimacy of the ethics code, titled Guidelines for Journalists, among Finnish journalists, with 88 per cent of the journalists considering the Guidelines useful and helpful to their work (Heinonen, 1995:17). In the early 2000s, support for the Guidelines was even more unequivocal at 95 per cent (Harju, 2002). In a 2011 survey, ${ }^{5} 90$ per cent of Finnish respondents agreed that the Guidelines have a tangible impact on their behaviour as journalists and no respondents denied their influence.

A key question is to what extent the ethical principles concerning the traditional media also apply to the 'new' media. Reuters Handbook of Journalism answers this question, arguing that the same standards of sourcing, identification and verification apply (Reuters, 2012). Furthermore, it says: 'Internet reporting is nothing more than applying the principles of sound journalism to the sometimes unusual situations thrown up in the virtual world'. However, in everyday work, 'the principles of sound journalism' are challenged when publishing online or using online resources for journalistic content. The ethics of journalism is indeed the never-ending task of inventing and reinterpreting journalism's moral framework, because the 'project of journalism' is ever changing (Ward, 2005:8). On the Internet, the project of journalism obtains new dimensions that affect a number of ethical issues, giving them a different significance for both journalists

\footnotetext{
${ }^{5}$ Online survey, conducted in 2011 by an EU funded project Media Accountability and Transparency in Europe among journalists of 12 European countries (Austria, Estonia, Finland, Germany, Italy, the Netherlands, Poland, Romania, Spain, Switzerland) and two Arab countries (Jordan and Tunisia) (total 1764 respondents). See www.mediaact.eu, date accessed 13 December 2012.
} 
and the public when compared with the pre-Internet era. Cooper (1998) lists 40 effects created by new technology that are inextricably linked to ethical issues. He argues that each new communication technology, either retrieves, amplifies, transforms, obsolesces, or mixes ethical issues from the past or creates new issues for the future. Deuze and Yeshua (2001) point out two crucial issues regarding the ethics of online journalism: credibility and verification of information. Both are affected by commercial pressure/competition, the use of hyperlinks and other ways of identification of sources, newsgathering methods, regulation, and protection of privacy.

One of the key moral issues in online journalism is the hazy separation between editorial and commercial information (Evers, 2001). In traditional journalism, editorial and commercial areas are explicitly separated and the reader usually easily recognises where advertising begins. In online publications, this separation no longer holds and the users do not always notice that they have stopped reading editorial content and continued with a commercial message. Comments and discussion forums hosted by news media do not usually form part of editorial content, but this is not always clear for the readers. Demarcation between editorial content, advertising and user-generated content is important from the viewpoint of regulation, as the responsibility for each content lies on different actors.

The possibility of using hyperlinks enables journalists to be more transparent about the sources of their stories and provide the readers with additional information about the issue concerned. On the other hand, the links may be misleading, or selectively used in order to support the idea of the story. Furthermore, it has become more difficult to assess who the original author is, and citing an Internet source often borders on the line of copying someone else's content, in turn raising issues of copyright and intellectual property (Deuze and Yeshua, 2001: 279).

The Internet has further made it possible to make private information an object of business. This is the case when collecting personal data of private citizens in order to sell it to advertisers. Such activities easily infringe people's privacy. The ethical question in relation to journalism is for what purposes news outlets have the right to gather personal data and what they are allowed to do with it. In Finland, registers containing personal data are allowed in editorial offices if they are maintained by publishers, in-house journalists or freelancers, and are used exceptionally as journalistic source material for stories. However, securing such data is required (Personal Data Act 523/1999).

Various ethical problems also arise in connection with newsgathering methods, e.g. being identified as a journalist when joining online groups; protecting sources, when every bit of information can be 'googled'; quoting e-mail messages in the stories, etc. Another important ethical issue concerns the online archives of news outlets, where the editorial offices are to decide what should be stored and preserved and what should not.

Finally, ethical problems can arise in connection with the use of images (both photographs and videos) produced by media users or citizen journalists. New technologies enable easy combination and alteration of images. The issue is "whether newsrooms can trust the easily obtained images of citizens and citizen journalists. /---/ Who is the sender and how do we know that this image is really of the event in question?” (Ward, 2012) 


\subsection{Self-regulation online}

The CMM provides a self-regulatory system for all Finnish media, including webpublications and traditional news media's online versions. Nearly all the Finnish media organisations have committed themselves to the CMM's objectives. The CMM operates since 1968, dealing with complaints by individuals, officials or organisations, which seek non-judicial resolutions to contested cases. Under certain circumstances involving important principles, the CMM can initiate an independent investigation.

In 2011, the CMM received 324 complaints (which is the largest number of complaints since 2000) and made 72 resolutions, 20 of which were upheld (Porra, 2012). The CMM has no other sanctions than obliging the news media concerned to publish the reprimanding adjudication without delay and without comments. The principles of publishing the adjudications have been adapted to the Internet era. A reprimanding adjudication must always be published on the website of the mass medium or news agency, if the medium in question has a significant amount of content on the web. In the case of a print outlet, alternatively, a news story or the adjudication in full should be published both in print edition and online. If the adjudication concerns an online-only publication, it is sufficient to publish it only online. Radio and television stations are required to publish a news item about the reprimand on the programme's website connected to the programme in question (Finnish Council for Mass Media, 2011).

In its rulings, the CMM relies on the Guidelines for Journalists, which are regularly updated (the latest version is operative from 1st January 2011). ${ }^{6}$ The Guidelines are remarkably more detailed than legal provisions and set very concrete rules for journalists concerning their responsibilities and rights irrespective of the publishing platform. The CMM also occasionally issues statements of a more general nature regarding important questions of professional ethics (Kuutti, Lauk and Lindgren, 2011).

In general, the CMM sees the Internet as another publishing platform among the traditional press, radio and television. Therefore, basically the same principles of good journalistic practice are to be followed in online publishing as in print or broadcasting. However, practices of opinion and discussion sites may remarkably differ from the journalistic practices in traditional news media. Therefore, the CMM emphasises the importance of differentiating clearly between the editorial and non-editorial content of the websites and providing the users with unambiguous guidelines of behaviour on these websites (Finnish Council for Mass Media, 2007).

The CMM generally regards consumer-produced content as subject to journalistic self-regulation. For that purpose, a special Annexe to the Guidelines has been added, which came into force on $1^{\text {st }}$ October 2011. The CMM has not, however, made any special statement about Facebook or other social media.

Along with the Guidelines for Journalists, the CMM's resolutions are important for evaluating journalistic practice online and for advancing ethical standards. The practices of online publishing can be divided into two broad groups: 1) journalistic decisions and practices of producing editorial content; and 2) supervision over the appropriateness of the discussion forums and comments on the news outlet's website.

\subsubsection{Ethical issues concerning editorial production online}

\footnotetext{
${ }^{6}$ See http://www.jsn.fi/en/journalists_instructions, date accessed 21 October 2012.
} 
According to the CMM, the five most frequent reasons for complaints from the public are: 1) publishing incorrect information and not correcting mistakes; 2) neglecting the right to reply; 3) violating human dignity; 4) 'hidden' advertising; and 5) headlines not corresponding to the substance of the story (Porra, 2012). Additional problems relate to the identification of sources (e.g. ignoring the rule of referring to other media as sources) and verifying facts. Using the same story in print, online, and on radio or television causes a new problem: although the Guidelines demand that journalists tell interviewees in which channel or platform their statements will be published, this is no longer always possible. Another question is whether the source should be informed if the full version of an interview in an offline medium can be read online.

Concerning editorial production online, the CMM has most frequently dealt with three issues: correction of mistakes, referencing the other media as sources and archiving online content. In the following, we focus on the principles formulated in the Guidelines and arising from the resolutions of the CMM related to these issues. ${ }^{7}$

\section{Correction of mistakes}

Correction of mistakes is a litmus test of reliability and accountability of a medium. Incorrect information on the Internet can spread at high speed in unlimited space. Therefore, the CMM emphasises the necessity of immediate correction, noting that it is essential to correct a mistake first online. If the mistake was made on a traditional news platform, it is not enough to correct only the offline version $(3775 \mathrm{~B} / \mathrm{SL} / 07)$. Also, the correction should be linked to the original incorrect story to inform the reader about both the mistake and correction. It is indeed not enough to remove the incorrect story from the web, as the search engines may still find it (4581/SL/11). In addition, the CMM suggests that when making a correction the news media should explain to the readers what has been corrected and why (4621/AL/11). Good journalistic practice consists of informing the readers about the mistake and taking care that the readers of the incorrect story will be directed to the correction (4581/SL/11).

\section{Referring to other media as sources}

'Professional communicators lose control over their messages as those messages become freely copied, exchanged, extended and challenged by anyone with a mind (and a modem) to do so' (Singer, 2007: 90). Increasingly, the 'exchange' of the content also happens between the news media outlets: topical stories 'travel' from one website to another, and their sources are not always referred to. The CMM suggests mentioning the name of the source medium already in the title, if all or most of the content comes from another medium. A reference to the original source must also be added to direct quotations. Furthermore, the story should be provided with a link to the original text or to the front page of the 'donor' medium, if a direct link to the original does not exist. This practice is considered to allow readers and the persons interviewed for the original story to check the correctness of their statements in the subsequent story (Finnish Council for

\footnotetext{
${ }^{7}$ The CMM resolutions (published in Finnish) which are quoted in the text can be accessed on the CMM website by their code numbers at: www.jsn.fi.
} 
Mass Media, 2010). The missing reference to the source should not be corrected by the removal of the story, but the link to the source should be added immediately when its absence is noticed (4431/SL/10). When picking up quotes from discussion forums for publishing in a story, their source should also be clearly displayed (3374/SL/04).

\section{Archiving}

The most complicated problem with news media's online archives relates to the protection of privacy. Through the likelihood of search engines finding the names of individuals mentioned in the stories, the so-called 'continuous publicising' effect emerges, which may influence their whole life span.

Finnish legislation does not regulate the archiving of the news media's online material, and news organisations decide about archives' content by themselves. The CMM stresses that the archives are history that should not acquire retrospective changes. However, in exceptional cases when the consequences of retaining the archived story unchanged or undeleted would cause major harm (especially concerning youngsters), the responsible editor may allow changes. Such cases can only be exceptions, and the readers should be informed about the changes (Finnish Council for Mass Media, 2009). In practice, the issue of the archives remains problematic, especially when the same story has been published in several news media. Deleting the story in the web archive of the original publisher does not affect the others, and search engines will still find it.

\subsubsection{Discussion forums and comments}

Giving the audience a voice is generally seen as media's contribution to the advancement of democracy in society (Earl and Kimport, 2011; Newman et al., 2012). This includes enabling people to contribute to the news content, offering them a space for open debate and discussion, and making it possible to instantly comment on the stories. However, as research seems to confirm, the actual participation of the members of the public in creating content for news sites is modest and participation in chat rooms and comment boxes appears mostly as giving feedback on the content others have created (Bergström, 2008; Hujanen and Pietikäinen, 2004). Chats and comments often contain inaccurate facts, confusing opinions and harmful statements. Furthermore, the news organisations rarely know the identity of sources of such content and cannot check the truthfulness of the postings. Hence, the news media organisations have introduced various practices of controlling communications that encourage violence, racism, hatred, xenophobia and disorder (Trygg, 2012).

Moderation of the forums and comments has triggered the question of whether or not the gatekeeping of public debates violates the people's right for free and secure communication. On the other hand, moderation is the news media's means for maintaining their credibility and keeping discussion and comment fields safe from harmful content. Difficulties, however, arise with respect to drawing a clear distinction between lawful and unlawful messages, especially concerning so-called 'border cases'. This distinction largely depends on the clarity and exhaustiveness of the moderation guidelines and commenting rules, and the level of knowledge and experience of moderators. 
Finnish legislation does not put responsibility for user-generated content on the news organisations; these have no obligation to moderate their public discussion rooms and comment boxes. The legality of this content (network messages) is the responsibility of the authors as defined in the Penal Code of Finland (39/1889). Because of the problems referred above, however, many Finnish news media have voluntarily begun to pre-moderate user-generated content. Taking voluntary responsibility for the entire online content indicates the growing accountability of Finnish media to society. Both the CMM and various news media have generated guidelines for moderation, as well as for posting comments and other content contribution online.

\section{Guidelines and interpretations of the CMM}

Already as early as in 2007, the CMM issued the first statement concerning online publications (Finnish Council for Mass Media, 2007). The statement pointed to the importance of openness and of clearly formulated rules of behaviour on the media websites. The CMM also suggested pre-moderation of discussions and comments, noting that post-moderation is also acceptable. However, in 2010, only about half of the news media pre-moderated their discussion forums (Malin, 2010), and since then the situation has not greatly changed. Publishing under an alias was seen as permissible by the CMM, when the identity of the sender was known to the news medium in question. The CMM further stressed that the users should be provided with an opportunity to inform the publisher about harmful messages and suggest their removal, as well as to be informed about the likelihood of their contribution being used elsewhere in the publication (Finnish Council for Mass Media, 2007).

In practice, however, the blurriness of the borderlines between editorial and other content online caused continuous problems, and in 2011, an Annexe to the Guidelines for Journalists was added to clarify the rules of publishing discussions and comments. Leaving consumer-produced content outside the publisher's responsibility may undermine the principle of media responsibility, according to the CMM. The Annexe declares that certain fundamental principles, like respecting privacy and human dignity, concern discussion boards and forums even if they do not contain editorial material and regardless of whether they are pre- or post- moderated. The guidelines also stress the obligation of the editorial offices to monitor their websites and to prevent publication of the harmful content. Online forums and websites directed at children and young people should be monitored with particular care. ${ }^{8}$

In its adjudications, the CMM weighs the balance between the citizens' freedom of speech and the news media's right to exercise online publishing policy, which may limit discussions and comments. The CMM sees moderation as part of the editorial freedom of decision-making; hence, the news media can set their own rules and limits for online discussions $(4621 / \mathrm{AL} / 11)$. Also, they have the right to delete messages that violate these rules (4433/SL/10). Limiting the discussions is ethically justified in case of messages violating human dignity or opinions disregarding discretion towards crime victims (4371/SL/10). On certain occasions, blocking the commenter's access to the site may also be justified (3956/SL/08). On the other hand, the CMM stresses the importance

\footnotetext{
${ }^{8}$ See http://www.jsn.fi/en/journalists_instructions, date accessed 21 October 2012.
} 
of resisting external attempts to force a news medium to restrict the discussions on political or societal issues, or public criticism (4139/SL/09). The right of rebuttal does not apply to discussion forums. Even in the case of becoming a target of harsh criticism, a participant in the forum cannot demand the right for publishing a reply in the newspaper's paper or online version (3436/SL/04).

\section{Guidelines and practices of moderation in Finnish news media}

All major news media moderate their websites and have formulated guidelines and rules for the authors of postings. The guidelines prohibit all kinds of unlawful messages, violation of copyright, product marketing and advertising. Mass postings and posting links to problematic contents are not permitted. Opinions of others should be respected, and exclaiming or shouts (e.g. by using block letters) are not acceptable. The major daily Helsingin Sanomat allows critical postings about itself, if critiques focus on the work and production of its journalists, and not on their personalities (Helsingin Sanomat, 2012). Some newspapers forbid using inappropriate pseudonyms, other persons' names, or pretending to be a representative of an authority or a webmaster.

All the guidelines specifically emphasise the personal legal responsibility of the authors of the postings. In addition, the CMM suggests that the newspapers' guidelines should also notify about the likelihood of publishing postings in the paper version (4364/PL/10). As the postings are voluntary decisions and under the responsibility of the authors, a newspaper can assume that their messages would not contain sensitive personal information, and therefore, is free to publish them at its own discretion (3959/SL/08).

According to a limited survey among Finnish newspapers, done by the authors for writing this chapter, the possibility of reporting about inappropriate messages and getting confirmation of the receipt is a general practice. Postings are usually not edited, but are published as they appear, or are deleted. In the place of a deleted message, a notice about the action is often left.

There is some variety in moderating practices. The web publications' own discussion forums and the open public forums may have the same moderator or they can be moderated separately. Most often, moderators are ordinary staff members who fulfil this task on the basis of work sharing, or are special web editors. The moderators do not necessarily have a journalistic background and do not always belong to the staff. National commercial television station MTV3 buys moderation service from an external company. Iltalehti employs IT students on a part time basis and also uses volunteers from among its active readers. By using external moderators, the web publications strive to stress the distinction between the editorial content and public discussions (Virranta, 2012).

Only on a few occasions problems have occurred concerning discussion forums. Regional newspaper Hämeen Sanomat temporarily closed its public forum, when the link to a short news story in the newspaper about an immigrants' centre was disseminated via an anti-immigrant blog, and caused hundreds of reactionary messages. MTV3 has sometimes closed the comment boxes because of too many abusive comments. 


\subsection{Social media}

Finnish news organisations encourage their journalists to use social media and create Facebook and Twitter accounts and blogs, as well as to participate in discussion forums (Ahlroth, 2011; STT, 2012; YLE 2010). Ward (2012) argues that 'the ethical challenge is to develop social media guidelines that allow reporters to explore the new media world but also to draw reasonable limits on personal commentary'. Journalists should remember that their sources and audiences regard them as their employers' representatives. They should follow the same values in social media that they follow in their journalistic work. For example, YLE emphasises credibility, independence and respect for human beings as core values that should be equally valued in social media (YLE, 2010).

Guidelines for journalists in social media do not contain strict bans. However, YLE, the Finnish News Agency (STT) and Helsingin Sanomat presume journalists to be discreet when dealing with employers' and staff's internal affairs. Journalists should not discuss confidential matters in social media even as private persons (Ahlroth, 2011; STT, 2012; YLE, 2010). Helsingin Sanomat encourages its employees to use the news organisation's own social media sites. Profiles and sites that include the logo of Helsingin Sanomat will thus be regarded as journalistic production of the newspaper, to which ethical guidelines and editorial responsibility apply similarly to the paper's website (Ahlroth, 2011).

\section{Conclusion}

Ethical issues in online journalism and publishing are yet not entirely mapped by relevant research, although a number of studies discuss them from various perspectives (Jönsson and Örnebring, 2011; Whitehouse, 2010; Hlavach and Freifogel, 2011). Furthermore, it will not be probably possible to draw a complete map of all ethical problems that the Internet creates for the news media, as both are 'living organisms' that are continuously developing. However, some regulation is necessary, in order to avoid or solve ethical problems, and to diminish possible harm that the misuse of Internet freedom can cause. Finland does not regulate the use of the Internet, but primarily adapts existing legislation to the changing situation. The statutory regulation is not aimed at limiting the freedom of expression, but rather at preventing its misuse. Hence, for developing practical guidelines for journalists (as well as for the public interacting with the media), a larger responsibility is left for self-regulation.

Taking into consideration Finland's long tradition of media self-regulation and the fact that nearly all news media have joined the CMM and are sensitive to its reprimands and resolutions, it seems that the heavier weight of the balance between state and selfregulation is on the side of self-regulation. The CMM has formulated guidelines in its special Annexe to the ethical code for journalists, in separate statements, and the adjudications of various cases. These cases reflect the multiplicity of online ethical issues and also indicate their dependence on the cultural context. The CMM encourages the media organisations to take responsibility for their online publications as entireties, in order to increase their credibility. Numerous news organisations have thus introduced their own in-house guidelines, which include principles of online behaviour for both 
journalists and their audience members. These guidelines are, in most cases, also available to the public, which definitely increases transparency and makes interaction with the public mutually easier.

\section{References}

Ahlroth, J. (2011) 'HS uudisti sosiaalisen median ohjeensa' [Helsingin Sanomat renewed its guidelines for social media], http://www.hs.fi/kulttuuri/HS+uudisti+sosiaalisen+median+ohjeensa/a1305548863985, date accessed 10 October 2012.

Akamai (2012) 'First quarter 2012. State of the internet report', http://www.akamai.com/stateoftheinternet, date accessed 11 August 2012.

Bergström, A. (2008) 'The reluctant audience: Online participation in the Swedish journalistic context', Westminster Papers in Communication and Culture, 5(2), 60.

Cooper, T.W. (1998) 'New technology effects inventory: Forty leading ethical issues', Journal of Mass Media Ethics, 13(2), 71.

Deuze, M., and D. Yeshua (2001) 'Online journalists face new ethical dilemmas: Lessons from the Netherlands', Journal of Mass Media Ethics 16(14), 273.

Deuze, M. (2003) 'The web and its journalisms: Considering the consequences of different types of newsmedia online', New Media \& Society, 5(2), 203.

Deuze, M. (2008) 'Understanding journalism as newswork: How it changes, and how it remains the same', Westminster Papers in Communication and Culture, 5(2), 4.

Earl, J., and K. Kimport (2011) Digitally enabled social change: Activism in the Internet age (Cambridge, MA: MIT Press).

Evers, H. (2001) 'New moral dilemmas in online journalism?' forum medienethik, 1, 37, http://www.european-

mediaculture.de/fileadmin/bibliothek/english/evers_journalism/evers_journalism.pdf, date accessed 10 November 2012.

Finnish Council for Mass Media (2007) 'Lausuma verkkojulkaisuista' [Statement on webpublications], 3741/L/07, http://www.jsn.fi/lausumat/lausuma-verkkojulkaisusta, date accessed 10 August 212.

Finnish Council for Mass Media (2009) 'Periaatepäätös verkkoarkistoista' [Resolution on web archives], 4069/SL/09, http://www.jsn.fi/periaatepaatokset/periaatepaatos-verkkoarkistoista, date accessed 10 August 2012.

Finnish Council for Mass Media (2010) 'Periaatelausuma lainaamisesta' [Statement on referencing], 4279/L/10, http://www.jsn.fi/periaatelausumat/lainaaminen, date accessed 5 September 2012. 
Finnish Council for Mass Media (2011) 'Basic agreement: Consequences of violation of good practice', http://www.jsn.fi/en/Council_for_Mass_Media/basic-agreement/ date accessed 8 June 2012.

Finnish Ministry of Justice (2011) 'Uudet rikoslain säännökset lisäävät verkon ylläpitäjien vastuuta' [New provisions in the criminal code increase responsibilities of web-administrators], http://www.om.fi/Etusivu/Ajankohtaista/Uutiset/Uutisarkisto/Uutiset2011/130267259182， date accessed 4 September 2011.

Hallin, D. and P. Mancini (2004) Comparing media systems: Three models of media and politics, Cambridge: Cambridge University Press.

Harju, A. (2002) Journalistisen työn sääntely ja ammattietiikka [Regulation of journalistic process and professional ethics] (Tampere: University of Tampere).

Heinonen, A. (1995) Vahtikoiran omatunto: Journalismin itsesääntely ja toimittajat [The Conscience of a Watchdog: Self-regulation and journalists],University of Tampere, Department of Journalism and Mass Communication Publications, Series A.

Helsingin Sanomat (2012) HS.fi-ohjeet [HS.fi guidelines] http://www.hs.fi/sivu/kommentointiohjeet, date accessed 10 June 2012.

Hlavach, L., and W.H. Freivogel (2011) 'Ethical implications of anonymous comments posted to online news stories', Journal of Mass Media Ethics, 26, (1), 21.

Hujanen, J., and S. Pietikäinen (2004) 'Interactive uses of journalism: Crossing between technological potential and young people's news using practices', New Media \& Society, 6 (3), 383.

Internet World Stats (2012), http://www.internetworldstats.com/stats4.htm, date accessed 10 November 2012.

Jönsson, A.M., and H. Örnebring (2011) 'User-generated content and the news', Journalism Practice, 5(2), 127.

Kansallinen Mediatutkimus (2012) 'Digilehti täydentää painettujen lehtien lukemista' [Reading digital newspapers complements reading of printed newspapers], http://www.levikintarkastus.fi/mediatutkimus/KMT_lukijatiedote_\%20syyskuu_2012.pdf date accessed 27 August 2012.

Kuutti, H., E. Lauk and M. Lindgren (2011) Does media policy promote media freedom and independence? The case of Finland, Case study report for the MEDIADEM project, www.mediadem.eliamep.gr/wp-content/upload/2012/01/Finland.pdf, date accessed 27 December 2012

Laine, J. (2010) Sosiaalisen median hyödyntäminen uutistoimittajan työssä [The use of social media in journalistic work] (Helsinki: Diakonia Polytechnic; unpublished BA- thesis).

Leets, L. (2001) 'Responses to internet hate sites: Is speech too free in cyberspace?', Communication Law \& Policy, 6(2), 287. 
Malin, V. (2010) ‘Asialinjalle!’ [To the business!], Suomen Lehdistö, 8-9, 4.

MTV3 (2011) 'Astrid Thorsia uhanneen tuomio koveni - lue oikeuden perustelut' [The sentence of the threatener of Astrid Thors was made tougher: read the reasonings of the court], http://www.mtv3.fi/uutiset/rikos.shtml/astrid-thorsia-uhanneen-tuomio-koveni---lue-oikeudenperustelut/2011/07/1357919, date accessed 12 August 2012.

MTV3 (2012) 'Lieksan Facebook-jutusta ehdotonta vankeutta yhdelle', [Jail sentence to one person for the Facebook story of Lieksa], http://www.mtv3.fi/uutiset/rikos.shtml/2012/05/1539305/lieksan-facebook-jutusta-ehdotontavankeutta-yhdelle, date accessed 12 August 2012.

Newman, N., W.H. Dutton and G. Blank (2012) 'Social media in the changing ecology of news: The Fourth and Fifth Estates in Britain', International Journal of Internet Science, 7(1), 6.

Pavlik, J (2000) 'The impact of technology on journalism', Journalism Studies, 1, (2), 229.

Perry, B., and P. Olsson (2009) 'Cyberhate: the globalization of hate', Information and Communication Technology Law, 18(2), 189.

Porra, N. (2012) 'New challenges in media ethics. A practical approach', Presentation at the seminar Journalists' Professional Autonomy and Journalism Ethics, University of Jyväskylä 14 June 2012, http://dl.dropbox.com/u/65586777/Mediadem/Porra.pdf, date accessed 5 September 2012 .

Reuters (2012), 'Reuters Handbook of Journalism' http://handbook.reuters.com/index.php/Reporting_From_the_Internet_And_Using_Social_Media, date accessed 11 November 2012.

Singer, J.B. (2007) ‘Contested autonomy’, Journalism Studies, 8 (1), 79.

STT (2012) 'STT-Lehtikuvan ohjeet sosiaaliseen mediaan' [STT-Lehtikuva's guidelines for social http://www.stt.fi/sites/default/files/uploads/8.3_sttlehtikuvan_ohjeet_sosiaaliseen_mediaan.pdf, date accessed 30 November 2012.

Trygg, S. (2012) 'Is comment free? Ethical, editorial and political problems of moderating online news', Nordicom-Information, 34(1), 3.

Virranta, R. (2012) 'Rajan vetäjä’ [The one who draws the limits], Suomen Lehdistö 4, 12.

Ward, S.J.A. (2005) 'Philosophical foundations for global journalism ethics', Journal of Mass Media Ethics, 20(1), 3.

Ward, S.J.A. (2012) 'Digital media ethics', http://ethics.journalism.wisc.edu/resources/digitalmedia-ethics/, date accessed 26 November 2012.

Whitehouse, G. (2010) 'Newsgathering and privacy: Expanding ethics codes to reflect change in digital media', Journal of Mass Media Ethics, 25 (4), 310. 
YLE (2010) 'YLE laati sosiaalisen median ohjeet' [YLE composed the guidelines for social media], http://yle.fi/uutiset/yle_laati_sosiaalisen_median_ohjeet/5688822, date accessed 12 January 2012.

YLE (2011) 'Netissä Vanhasta ja Kataista uhkailleen miehen syytteen nurin' [The charges against the man who threatened Vanhanen and Katainen online were dropped] http://yle.fi/uutiset/netissa_vanhasta_ja_kataista_uhkailleen_miehen_syytteet_nurin/2262527, date accessed 10 November 2012. 